\title{
REQUIREMENTS TOWARDS THE TECHNOLOGY OF CONSTRUCTION OF PIPELINES CROSSINGS BY DIRECTIONAL DRILLING METHOD
}

. . пектор, . . р футдинов, . . олоф ст

Yu. I. Spektor, Z. Z. Sharafutdiniov, S. L. Golofast

« зпром промг з», г. оскв

юменский госуд рственный нефтег зовый университет, г. юмень

\author{
лючевые слов : подводный переходм гистр льного трубопровод ( $\quad$ ); технология \\ строительств ; н клонно-н пр вленное бурение; буров я уст новк ; породор зрущ ющий \\ инструмент; технология р сиирения скв жины переходов; утилиз ция отходов \\ Key words: underwater crossing of the main pipeline; underwater crossing construction technology; \\ directional drilling; drill rig; rock breaking tool; method of well crossing widening; wastes disposal
}

троительство переходов трубопроводов через естественные и искусственные водные прегр ды способом н пр вленного бурения получило широкое р спростр нение в мировой пр ктике. нный метод обеспечив ет высокую эксплу т ционную н дежность переходов, исключ ет возможность внешних воздействий н трубопровод и позволяет прокл дыв ть трубопроводы н переход х, где применение тр ншейных способов технически невозможно или трудновыполнимо. 
последние годы способом н пр вленного бурения построено зн чительное количество подводных переходов в р зличных горно-геологических условиях, х р ктеризующихся широким ди п зоном изменения условий бурения. есмотря н зн чительный объем , построенных в и других стр н х, недост точно прор бот ны технологические нормы контроля для проектиров ния и строительств методом н клонно-н пр вленного бурения. ряде случ ев, особенно по мере усложнения горногеологических условий строительств , это приводит к возникновению в рийных ситу ций, резкому увеличению з тр т н строительство или д же к потере строящегося переход . этому были изучены условия и про н лизиров н опыт строительств что позволило нормиров ть технологические спекты процесс в проектиров нии строительств , д ть проектные решения по строительству, обеспечить требуемый контроль. се это помогло снизить стоимость их строительств, огр ничить возможность созд ния в рийных ситу ций и предотвр тить возможность потери

р ктеристик условий строительств подводных переходов. ледует выделить ф кторы, препятствующие строительству подводных переходов.

- евозможность строительств подводного переход по причине горногеологических условий, х р ктеризующихся несовместимостью условий бурения с техническими возможностями способ . римером этому может служить н личие в лунного м тери л более $15 \%$, повышенн я к рстовость к рбон тных пород и р змер полостей более 2-3 м, мерзлый г лечник и т. п.

- $\quad$ кономические сообр жения по строительству подводного переход в тех или иных горно-геологических условиях.

- $\quad$ едост точн я технологическ я подготовленность бурового персон л . то приводит к повышенной в рийности при строительстве подводных переходов.

- $\quad$ тсутствие у подрядчик бурового оборудов ния, необходимого для успешного строительств подводного переход . одобные ф кты вызыв ют з медление сроков строительств подводных переходов и требуют зн чительных 3 тр т времени н ликвид цию технических осложнений.

ким обр зом, н техническую сложность строительств переходов м гистр льных нефтепроводов (переходов) ок зыв ют влияние конструктивные п р метры подводных переходов и технические возможности имеющегося оборудов ния, но определяющую роль игр ют горно-геологические условия бурения и совместимость р зличных интерв лов бурения для ре лизуемой технологии. гр ничением будет являться т кже и экономическ я целесообр зность ре лиз ции технологии н пр вленного бурения. случ е приближения величины 3 тр т н бурение к 3 тр т м н сооружение микротоннеля или в случ е невозможности бурения необходим ре лиз ция микротоннельного способ строительств переходов трубопроводов.

н лиз з тр т н строительство р зличных переходов, приведенный н рисунке, пок зыв ет, что стоимость строительств переходов пл вно р стет до величины конструктивного п р метр $\mathrm{L} * \mathrm{D} \approx 500-600$ (где $\mathrm{L}$ - длин переход , D - ди метр трубопровод ). д дннй гр ницей необходимо изыск ние дополнительных технических резервов для снижения 3 тр т н строительство переходов методом н пр вленного бурения. ним можно отнести многоступенч тое р сширение, новые типы породор зруш ющего инструмент, совершенствов ние технологии ведения р бот, снижения з тр т н буровой р створ и др. ольшинство переходов, имеющих конструктивный п р метр L*D менее 600, строились с высокой скоростью, не имели в рийных ситу ций и т. п.

6 этом т кже свидетельствуют д нные по з тр т м времени н основные опер ции строительств переходов: бурение пилотной скв жины, ее р сширение и прот скив ние трубопровод . ост з тр т времени х р ктерен лишь для переходов, осуществлявших бурение в высокопл стичных глин х, т кже в условиях, х р ктеризующихся н личием в лунного м тери л , в прочных к рбон тных пород х, гр вийно-г лечниковых и щебенистых отложениях, т кже в твердых глин х и мергелях. увеличением конструктивного п р метр $\mathrm{L}^{*} \mathrm{D}>400-500$ з тр ты времени н строительство переходов возр ст ют более интенсивно, особенно в осложненных условиях бурения.

збиение построенных переходов по цикловой скорости строительств позволяет выделить, что вне 3 висимости от величины L*D их можно $\mathrm{p}$ зделить н три времен- 
ные к тегории и н основ нии этого осуществлять прогноз з тр т времени н строительство переходов.

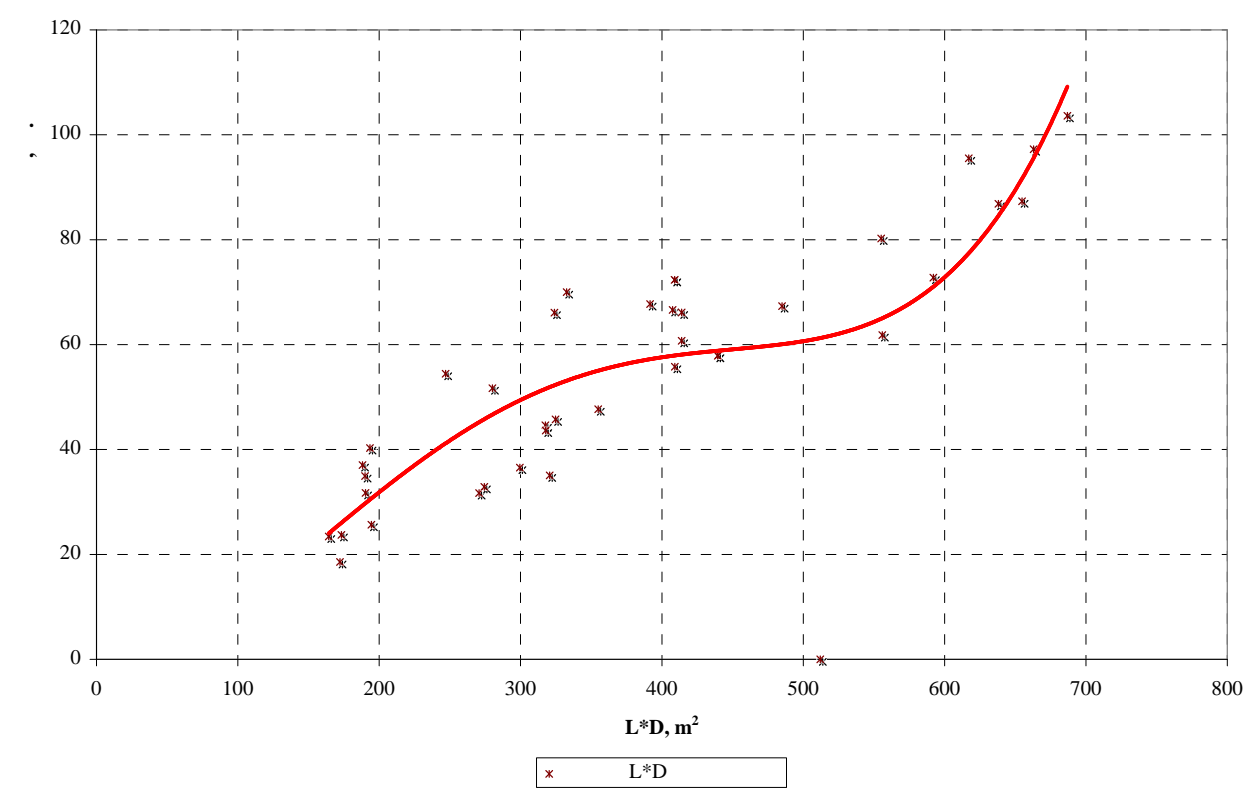

исунок. спределение з тр тн строительство переходов трубопроводов в з висимости от его конструктивных $n$ р метров

ти же результ ты позволяют р збить строительство переходов по групп м технологической усложненности ведения буровых $\mathrm{p}$ бот исходя из н $\mathrm{p}$ бот нного резерв по технологии бурения в тех или иных горно-геологических условиях. одобную инженерно-техническую оценку горно-геологических условий и результ тов строительств подводных переходов можно свести в т бл. 1.

блии 1

спределение переходов по трудности р зр ботки методом н пр вленного бурения

\begin{tabular}{|c|c|c|}
\hline \multirow{3}{*}{$\begin{array}{l}\text { ременн я } \\
\text { К тегория } \\
\text { сложности }\end{array}$} & \multirow{3}{*}{$\begin{array}{l}\text { рупп } \\
\text { технологической } \\
\text { сложности }\end{array}$} & $\begin{array}{l}\text { p ктеристик к тегорий по конструктивному п р метру } \\
\text { переходов, литологическому сост ву и условиям бурения }\end{array}$ \\
\hline & & \begin{tabular}{c|c} 
I групп & II групп \\
\end{tabular} \\
\hline & & $\mathrm{L}^{*} \mathrm{D}>500$ \\
\hline \multirow[b]{2}{*}{ I } & 1 & $\begin{array}{l}\text { ередов ние по стволу скв жины и однородное } 3 \text { лег ние моно- } \\
\text { литных пород 1-2 к тегории прочности и песков }\end{array}$ \\
\hline & 2 & $\begin{array}{l}\text { днородное } 3 \text { лег ние и чередов ние по стволу скв жины пород } \\
1-2 \text { к тегории прочности с гр вийно-г лечниковыми или щебени- } \\
\text { стыми отложениями, содерж щих песч ный или глиносодерж щий } \\
3 \text { полнитель более } 40 \% \text {, с их мощностью по стволу скв жины не } \\
\text { более } 100 \text { м. }\end{array}$ \\
\hline \multirow[t]{2}{*}{ II } & 3 & $\begin{array}{l}\text { днородное } 3 \text { лег ние и чередов ние по стволу скв жины моно- } \\
\text { литных пород 1-2 к тегории прочности с гр вийно-г лечниковыми } \\
\text { или щебенистыми отложениями, содерж щих песч ный или глино- } \\
\text { содерж щий з полнитель более } 40 \% \text {, с их мощностью по стволу } \\
\text { скв жины более } 100 \text { м. }\end{array}$ \\
\hline & 4 & $\begin{array}{l}\text { ередов ние по стволу скв жины и однородное } 3 \text { лег ние } 3 \text { к p- } \\
\text { стов нных пород } 3-4 \text { к тегории прочности с р змером полостей не } \\
\text { более } 2 \text { м. } \quad \text { личие высокопл стичных монолитных грунтов }\end{array}$ \\
\hline
\end{tabular}


родолжение $m$ бл. 1

\begin{tabular}{|c|c|c|}
\hline \multirow{3}{*}{$\begin{array}{l}\text { ременн я } \\
\text { К тегория } \\
\text { сложности }\end{array}$} & \multirow{3}{*}{$\begin{array}{l}\text { рупп } \\
\text { технологической } \\
\text { сложности }\end{array}$} & $\begin{array}{l}\text { p ктеристик к тегорий по конструктивному п р метру } \\
\text { переходов, литологическому сост ву и условиям бурения }\end{array}$ \\
\hline & & \begin{tabular}{|c|c} 
I групп & I групп \\
\end{tabular} \\
\hline & & $\mathrm{L} * \mathrm{D}<500$ \\
\hline II & 5 & $\begin{array}{l}\text { ередов ние по стволу скв жины и однородное з лег ние моно- } \\
\text { литных пород } 3-4 \text { к тегорий прочности. личие гр вийно- } \\
\text { г лечниковых и щебенистых отложений с содерж нием песч ного } \\
\text { или глиносодерж щего } 3 \text { полнителя менее } 40 \% \text { с мощностью } \\
3 \text { лег ния по стволу скв жины более } 100 \text { м. }\end{array}$ \\
\hline \multirow{3}{*}{ III } & 6 & $\begin{array}{l}\text { Зновысотность точек вход и выход более } 20 \text { м. ередов ние по } \\
\text { стволу скв жины пород с } \text { р зными к тегориями прочности } \\
(1-5 \text { к тегория прочности) }\end{array}$ \\
\hline & 7 & $\begin{array}{l}\text { ередов ние по стволу скв жины и однородное } 3 \text { лег ние пород } \\
5-6 \text { к тегории прочности. личие к рстовых полостей р змером } \\
\text { более } 2 \text { м }\end{array}$ \\
\hline & 8 & $\begin{array}{l}\text { онолитные породы 1-2 к тегории прочности, содерж щие высо- } \\
\text { копрочные включения в виде в лунник, в лунов с р змером не } \\
\text { более } 300 \text { мм. опуск ется содерж ние в лунов не более } 20 \%\end{array}$ \\
\hline
\end{tabular}

ыбор буровых уст новок и бурового оборудов ния для строительств скв жины подводного переход . ри строительстве подводных переходов трубопроводов используются буровые уст новки средней и большой мощности. редние буровые уст новки с м ксим льным тяговым усилием до 40 т и крутящим моментом до 30 к м применяются н переход х трубопроводов небольшого ди метр через м лые реки. ост льных случ ях применяются большие и сверхбольшие уст новки по кл ссифик ции, приведенной ниже

$\begin{array}{cc}\text { уровые } & \text { ксим льн я } \\ \text { уст новки (тип) } & \text { сил тяги, тс } \\ \text { редние } & >15,0 \leq 40,0 \\ \text { ольшие } & >40,0 \leq 250,0 \\ \text { верхбольшие } & >250,0\end{array}$

$\begin{array}{cc}\text { ксим льный } & \\ \text { крутящий момент, к } & \text { м }, \mathbf{T} \\ 10-30 & 10-25 \\ 30-100 & 25-60 \\ >100 & >60\end{array}$

уров я уст новк должн созд в ть усилие, не менее чем в 2 р 3 превыш ющее p счетную величину тягового усилия (с учетом возможного ее увеличения при обрушении стенок и сужении ствол скв жины). ри этом н пряжения в трубопроводе от тяговых усилий не должны превыш ть допустимых величин.

н стоящее время не существует общепринятой модели р счет тягового усилия, н которое необходимо ориентиров ться при выборе буровой уст новки. чевидно, что это усилие должно быть существенно больше р счетного усилия прот скив ния трубопровод в скв жине. ри р счете усилий прот скив ния учитыв ются весовые $\mathrm{x}$ р ктеристики трубопровод и тяговой колонны, взвешив ющие силы бурового р створ , силы трения трубопровод н роликовых опор х и в скв жине, соответствующие длины уч стков, р диусы кривизны скв жины и другие ф кторы.

ост в оборудов ния по приготовлению и очистке бурового р створ , используемого при строительстве переходов, определяется исходя из условий его строительств , свойств бурового р створ и р змер ч стиц выбуренной породы, выносимых из скв жины. лок приготовления ( ) и очистки бурового р створ состоит из емкостей очистки, вибросит , пескоотделителя, илоотделителя, центробежных н сосов, смесителя, р бочей емкости н $10 \mathrm{~m}^{3}$. иболее прост я технологическ я схем по приготовлению бурового р створ включ ет в себя емкость для перемешив ния компонентов бурового p створ, котор я может быть осн щен мех ническими и гидр влическими перемешив телями; гидроэжекторным смесителем с з грузочной воронкой и шиберным 3 твором; центробежным или поршневым н сосом (обычно один из подпорных н сосов) и м нифольд ми.

ип применяемых бурильных труб з висит от силы тяги и крутящего момент , pe лизуемых в процессе бурения. урильн я колонн должн выдержив ть м ксим льные ожид емые н грузки н сж тие, р стяжение, кручение и изгиб с учетом коэффициент 
безоп сности. к пок зыв ет опыт бурения, н иболее ч сто р зрушению подверг ются элементы компоновки перед р сширителем (по телу бурильной трубы и в резьбовых соединениях). урильные трубы подверг ются сильному износу, особенно при бурении твердых пород с бр зивными включениями.

ородор зруш ющий инструмент, используемый в строительстве подводных переходов, можно р зделить в соответствии с подход ми, ре лизуемыми в [1], н :

- гидромониторный породор зруш ющий инструмент;

- инструмент режуще-ск лыв ющего действия ( ) - вооружение выполняется в виде лоп стей с режущей кромкой, котор я во время бурения н ходится в постоянном конт кте с р зруш емой породой;

- дробяще-ск лыв ющего действия (ш рошечные) - вооружение в виде фрезеров нных зубьев или вст вных зубков р змешено н ш рошк х, и во время бурения к ждый элемент имеет кр тковременный периодический конт кт с з боем.

о н зн чению породор зрущ ющий инструмент, используемый для строительств скв жин подводных переходов, делится н две группы: для бурения пилотной скв жины, для р сширения пилотной скв жины. ринципи льным отличием для $p$ зличных конструкций породор зруш ющего инструмент, кроме их функцион льного н зн чения, будет являться лишь принцип воздействия н 3 бой. ля бурения пилотной скв жины в основном используют тот же породор зруш ющий инструмент, что и для бурения глубоких скв жин. ля р сширения используются р сширители режущеск лыв ющего тип (Fly Cutter, Barrel Reamer), т кже р сширители дробящеск лыв ющего действия (Hole Opener). отдельных конструкциях р сширителей имеет место комбиниров ние р зличных схем р зрушения породы.

онструкция породор зруш ющего инструмент является в жным ф ктором для успешного строительств переходов. то обусловлено тем, что р сширители могут иметь ди метр до 1600 мм. дним из ф кторов, отвеч ющих 3 р зрушение горной породы, является количество элементов вооружения и их р сст новк по площ ди инструмент , что отр ж ется н перекрытии площ ди з боя р зруш ющими элемент ми и их эффективной одновременной р боте. ля этого необходим оптимиз ция количеств р зруш ющих элементов с ч стотой вр щения инструмент н 3 бое скв жины, что влияет н время конт кт р зруш ющего элемент с з боем скв жины. птим льн я величин количеств р зруш ющих элементов для р сширителей з висит от ди метр р сширителя, поэтому для успешного $\mathrm{p}$ зрушения породы н з бое скв жины необходимо увеличив ть $\mathrm{p}$ змер секторов, осн щенных $\mathrm{p}$ зруш ющими элемент ми, и количество с мих р зруш ющих элементов. пр ктической деятельности это н ходит отр жение, н пример, в увеличении р змер ш рошек н р сширителе или их количеств . пример, с увеличением ди метр р сширителя необходимо увеличив ть и количество р зруш ющих элементов.

ородор зруш ющий инструмент гидромониторного действия используется только при бурении мягких, рыхлых несцементиров нных грунтов до 1 к тегории прочности, для которых дост точно лишь соблюдение гидр влической прогр ммы бурения, процесс $\mathrm{p}$ зрушения идет з счет р змыв грунт (породы) [1]. сновным требов нием к их конструкции является бр зивн я устойчивость, н личие н с док требуемого ди метр и количеств . оличество н с док выбир ется исходя из производительности н сос .

ородор зруш ющий инструмент режуще-ск лыв ющего действия. д нному типу инструмент относятся лоп стные долот , т кже р сширители Fly Cutter и Barrel Reamer. зрушение горной породы при р боте инструмент режуще-ск лыв ющего действия осуществляется рез нием-ск лыв нием и истир нием при совместном действии норм льных и т нгенци льных н пряжений. роцесс р зрушения породы в этом случ е является прерывистым, возник ют колеб ния инструмент и дин мические н грузки н него. ри прочих р вных условиях дин мичность тем меньше, чем больше число лоп стей. ем больше лоп стей имеет породор зруш ющий инструмент, тем ближе сечение скв жины к круглому. то одн из причин, по которой р сширитель должен иметь конструкцию с числом лоп стей (секторов) более 5-6 или обл д ть бочкообр зной формой. ти положения будут спр ведливы для всех типов $\mathrm{p}$ сширителей.

целью уменьшения мплитуды поперечных колеб ний режущие кромки лоп стей необходимо готовить т к, чтобы обр зуемый ими з бой имел выпуклую форму, перед породор зруш ющим инструментом и после уст н влив ть центр торы-к либр торы, или же инструмент должен выполняться в бочкообр зной форме (р сширитель Barrel

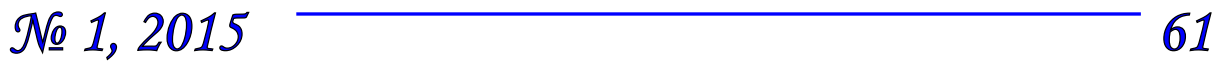


Reamer). очкообр зный корпус р сширителя имеет двойное н зн чение: уменьш ть дин мические колеб ния инструмент, способствов ть дополнительному выносу шл м и к либровке скв жины.

сширитель Fly Cutter отлич ется тем, что при бурении обр зуется крупный p 3мер ч стиц шл м, поэтому д нный тип р сширителей чрезвыч йно требов телен к объему промывки и к честву буровых р створов. есоблюдение условий промывки при его р боте ведет к формиров нию н них с льников, что созд ет технологические осложнения при бурении и увеличив ет непроизводительное время бурения. нный тип инструмент неприменим при бурении в твердых глин х, гр вийно-г лечниковых отложениях.

сширитель Barrel Reamer неэффективен в бр зивных пород х, т кже в гр вийно-г лечниковых грунт х, т к к к это ведет к износу его корпус . ля повышения эффективности его р боты в ряде случ ев производители буровых р бот дополнительно осн щ ют ш рошечным вооружением. ри р боте в гр вийно-г лечниковых грунт х с содерж нием песч ного з полнителя менее 40-50\% он не способен упрочнять ствол скв жины д же при повышении структурно-мех нических свойств бурового р створ . то обусловлено особенностями действия корпус р сширителя н з бой скв жины.

ородор зруш ющий инструмент дробяще-ск лыв ющего действия. рошечные долот для бурения сплошным з боем н шли широкое применение в глубоком бурении [2]. х используют для прохождения пород более второй к тегории прочности совместно с з бойным двиг телем. рошечные $\mathrm{p}$ сширители, используемые при р сширении пилотного ствол скв жины до требуемого р змер , именуются Hole Opener. онструкция т ких р сширителей отлич ется зн чительным многообр зием, они з висят от ди метр , способ р сширения пилотной скв жины - одноэт пный или многоэт пный. ех ническ я скорость бурения з висит от ди метр р сширителя и меняется в широком ди п зоне зн чений $0,5-10$ м/ч.

бщим для них является осн щение сл боконусными ш рошк ми или л п ми ш рошечного долот . оличество ш рошек в р сширителях меняется от 4 до 8 . сож лению, их количество не всегд оптимизируется по отношению к р збурив емой породе, и они не являются сменным элементом в конструкции р сширителя. мен ш рошек предусмотрен только в р сширителях конструкции фирмы INROCK.

сширители Hole Opener, используемые для одноэт пного р сширения, имеют, к к пр вило, щитовую конструкцию. х общим недост тком является то, что они обл д ют м лым числом породор зруш ющих элементов (ш рошек) и ост вляют зн чительные простр нств между своими р бочими элемент ми. то приводит к тому, что при бурении д нное простр нство з бив ется шл мом, обр зуются с льники, препятствующие эффективному $\mathrm{p}$ зрушению породы. одобные $\mathrm{p}$ сширители требуют повышенного р сход буровых р створов с высокими структурно-мех ническими свойств ми. ри бурении в прочных пород х они позволяют ре лизов ть величину мех нической скорости бурения 0,1-4 м/ч с.

одобные конструкции р сширителей, позволяют успешно строить скв жины и обеспечив ть прот скив ние трубопровод в несцементиров нных пород х, то есть в условиях з лег ния гр вийно-г лечниковых и щебенистых грунтов. то обусловлено влиянием д вления $\mathrm{p}$ сширителя н 3 бой, сложенный несцементиров нными отложениями гр вийно-г лечниковых и щебенистых грунтов. яговое усилие, действующее н р сширитель, уплотняет грунт н его периферии с одновременным н сыщением грунт буровым р створом, обл д ющим высокими структурно-мех ническими свойств ми. то обеспечив ет зн чительное упрочнение несцементиров нных отложений н стенке скв жины. одобный эффект увеличив ет эффективность $p$ боты одноэт пных, щитовых р сширителей Hole Opener.

рошечные р сширители, используемые для ступенч того р сширения, не пок зыв ют подобной эффективности при строительстве скв жин в условиях з лег ния гр вийно-г лечниковых и щебенистых грунтов. дн ко использов ние многоэт пного p сширения в устойчивых грунт х более 2 к тегории с помощью ш рошечных р сширителей позволяет з счет уменьшения площ ди з боя обеспечить высокие мех нические скорости бурения и успешное строительство подводных переходов.

ехнология р сширения скв жины переходов. сширение скв жины переходов может выполняться 3 один проход р сширителя м ксим льного ди метр или путем 
последов тельного ступенч того увеличения ди метр ствол скв жины с применением нескольких типор змеров р сширителя.

реди специ листов, з ним ющихся проблем ми строительств подводных переходов методом н пр вленного бурения, идет широк я дискуссия о предпочтительности того или иного способ р сширения скв жин. онечным критерием успешности строительств подводных переходов является успешное прот скив ние трубопровод в построенную скв жину, коммерческ я скорость строительств, т кже объем фин нсиров ния, необходимого для успешного строительств переход .

p внение между собой результ тов ре лиз ции одно-, многоступенч того р сширения позволяет выделить следующее. дноэт пный способ р сширения н иболее предпочтителен в строительстве переходов, отлич ющихся н личием в р зрезе ствол скв жины несцементиров нных пород в виде гр вийно-г лечниковых, щебенистых отложений. $\mathrm{p}$ ничной величиной эффективного использов ния одноэт пного способ p сширения являются подводные переходы с конструктивным п р метром до величины L*D < 500-600 м². ри отсутствии осложненных зон бурения, т ких к к отложения гр вийно-г лечниковых и щебенистых грунтов, многоэт пный и одноэт пный способы p сширения при L*D $<600 \mathrm{~m}^{2}$ сопост вимы. устойчивых грунт х при геометрической х р ктеристике подводного переход $\mathrm{L}^{*} \mathrm{D}>500-600 \mathrm{~m}^{2}$ н иболее предпочтителен многоэт пный способ р сширения.

ромывк ствол скв жины ир сход бурового р створ при строительстве переходов. н чительную роль в формиров нии прогр ммы промывки скв жины игр ют реологические п р метры буровых р створов. ни определяют вынос выбуренной породы н дневную поверхность, величину гидродин мического д вления в скв жине.

н лиз выносных свойств бурового р створ пок зыв ет, что при превышении ди метр скв жины более 600 мм зн чения величины скоростного н пор чрезвыч йно м лы и несущ я способность бурового р створ определяется только величиной предельного дин мического н пряжения сдвиг .

н я прев лирующий р змер ч стиц шл м горной породы в скв жине, прогнозируя их вынос из скв жины, можно определить безоп сное содерж ние шл м в буровом р створе для без в рийного бурения. еличины допустимого содерж ния шл м , ре лизов нные в пр ктической деятельности, приведены в т бл. 2.

н ние величин допустимого содерж ния шл м позволяет ре лизов ть следующий технический подход. счет необходимой под чи н сосов следует вести из условия величины мех нической скорости бурения, ре лизуемой при строительстве скв жины подводного переход . счет под чи н coc Q определится к к

$$
Q_{1}=\frac{F_{Z} * V}{C}
$$

где $Q_{1}$ - под ч бурового н сос из условия безоп сного содерж ния шл м , $\mathrm{M}^{3} / 4 \mathrm{c} ;$ $V+$ мех ническ я скорость бурения, м/ч с; $F_{Z}-$ площ дь з боя, м² — допустим я доля шл м в объеме бурового р створ , д. е.

опустимое содерж ние ил м в объеме бурового р створ при строительстве скв жины переход

\begin{tabular}{|c|c|c|c|}
\hline \multirow{2}{*}{$\begin{array}{c}\text { орно-геологические условия } \\
\text { строительств }\end{array}$} & \multicolumn{3}{|c|}{$\begin{array}{c}\text { опустимое содерж ние шл м } \\
\text { в объеме бурового р створ } \%\end{array}$} \\
\cline { 2 - 4 } & $\begin{array}{c}\text { илотн я } \\
\text { скв жин }\end{array}$ & $\begin{array}{c}\text { дноэт пное } \\
\text { р сширение }\end{array}$ & $\begin{array}{c}\text { ногоэт пное } \\
\text { сширение }\end{array}$ \\
\hline л, глинистые отложения, песок & $1-2$ & $10-20$ & $20-30$ \\
\hline ысокопл стичные глинистые отложения & $1-2$ & 10 & $10-15$ \\
\hline $\begin{array}{c}\text { р вийно-г лечниковые, щебенистые } \\
\text { отложения }\end{array}$ & $1-5$ & 10 & ецелесообр зно \\
\hline к льные породы невысокой прочности & $3-5$ & 10 & $20-30$ \\
\hline рочные ск льные породы & $3-5$ & 10 & $20-30$ \\
\hline
\end{tabular}


p внение технологий одноэт пного и многоэт пного р сширения (при фиксиров нном содерж нии шл м и мех нической скорости бурения) пок зыв ет, что при многоэт пном р сширении ст новится возможным снизить под чу бурового р створ .

нный эффект достиг ется з счет снижения величины площ ди з боя. оэтому в процессе строительств подводных переходов скорость бурения огр ничен производительностью блок по приготовлению бурового р створ . пример, при под че н сос 30 л/с, ди метре скв жины 1600 мм скорость бурения не должн превыш ть 5-6 м/ч с.

счет под чи н сос для многоэт пного р сширения с использов нием $\mathrm{p}$ сширителя Barrel Reamer осуществляется по условию ре лиз ции гидромониторного эффект для очистки з боя или р зрушения породы. сходя из этих условий, под ч бурового р створ определяется по формуле [1]

$$
Q_{2}=Q_{Y}+0,95 * f * \sqrt{\frac{2 \Delta P_{\partial}}{\rho_{\sigma p}}}
$$

где $Q_{2}$ - под ч бурового р створ из условия ре лиз ции гидромониторного эффект н породор зруш ющем инструменте, м $^{3} / \mathrm{c} ; Q_{Y}-$ утечки через уплотнительный узел в л гидр влического з бойного двиг теля, $\mathrm{m}^{3} / \mathrm{c} ; \Delta P_{\partial}-$ переп д д вления в породор зруш ющем инструменте, $\quad ; \rho_{6 p}-$ плотность бурового р створ, кг $/ \mathrm{M}^{3} ; f-$ площ дь гидромониторных н с док.

од ч бурового р створ для р боты гидромониторных н с док и ре лиз ции гидромониторного эффект н много ниже, чем под ч бурового р створ из условия безоп сного содерж ния шл м для проводки скв жины. оэтому р счет производительности н сос более целесообр зно проводить по уровню безоп сного содерж ния шл м в процессе бурения.

едост тком известных методов р счет р сход бурового р створ является то, что при них не учитыв ется кв лифик ция бурового подрядчик , его опыт р боты, используемый породор зруш ющий инструмент и многие другие ф кторы. ехнически н иболее корректным будет являться р счет объем р створ, потребляемого в процессе бурения, исходя из возможности ре лиз ции той или иной величины мех нической скорости бурения, з тр т времени н ликвид цию технических осложнений. оэтому спр ведливым будет подход к р счету р сход бурового р створ в процессе бурения по пути, когд $\mathrm{p}$ сход бурового р створ будет определяться необходимой под чей бурового р створ н время его производительного использов ния

$$
\begin{gathered}
V_{б p}=Q^{*} T, \\
Q=Q_{6 y p}-\vartheta^{*} Q_{\text {возвр } m}+Q_{\text {погл }}, \\
Q_{6 y p}=Q_{1}=\vartheta^{*} Q_{6 n_{-} \sigma p}, \\
={ }_{6 y p}+{ }_{\text {осл }},
\end{gathered}
$$

где $Q_{1}, Q_{\text {бур }}, Q_{\text {бльбр }}, Q_{\text {возвр } m}, Q_{\text {погл }}-$ соответственно под ч бурового р створ , необходим я для поддерж ния проектной величины мех нической скорости бурения, производительность блок по приготовлению бурового р створ, производительность блок по регенер ции бурового р створ, интенсивность поглощения бурового р створ в процессе бурения, $\mathrm{M}^{3} / ч ; v-$ количество блоков по приготовлению или регенер ции бурового $\mathrm{p}$ створ ; $\mathrm{T}_{\text {бур }}, \mathrm{T}_{\text {осл }}$, - 3 тр ты времени н мех ническое бурение, ликвид цию осложнений, время производительного использов ния бурового р створ , ч.

ля р счет объем потребляемого бурового р створ выр жение 4 можно 3 пис ть следующим обр зом:

$$
Q=Q_{\text {бур }}+Q_{\text {погл }}-Q_{\text {возвр } m}=Q_{\text {бур }}\left(1+K_{\text {погл }}\right)-Q_{\text {возвр } ~}
$$


или

$$
Q=Q_{1}\left(1+K_{\text {погл }}\right)-Q_{\text {возвр m }},
$$

где ${ }_{\text {погл }}=V_{\text {погл }} / V_{\text {бр }}-$ коэффициент потери циркуляции.

ля оценки производительного времени использов ния бурового р створ необходимо пользов ться д нными по времени, з тр чив емому буровым персон лом н процессы бурения пилотной скв жины, р сширения, к либровки и прот скив ния. полевых условиях необходимую под чу н сос можно вести по формуле

$$
Q_{1}=\frac{F z * V}{1-K} * \frac{\rho-\alpha * \rho}{\rho-\rho}
$$

где $\rho, \rho, \rho-$ плотности р збурив емой породы, бурового р створ , выходящего из скв жины, з к чив емого в скв жину; $\alpha$ - степень вынос шл м р збуренной породы из скв жины, д. е.

ыбор тип и п р метров буровых р створов, компонентов для его приготовления и обр ботки является в жным ф ктором, способствующим без в рийной проводке скв жины и охр не окруж ющей среды. сновным элементом, определяющим эффективность промывки скв жины в процессе бурения, является сост в бурового р створ и соответствие его свойств и р сход геолого-техническим условиям бурения.

уровой р створ должен обеспечив ть ст бильность глинистых отложений в процессе бурения. нный вопрос не является кту льным при строительстве подводных переходов с длиной менее 500 м. величение длины строительств подводного переход, н личие в р зрезе ствол скв жины высокопл стичных и осып ющихся глинистых отложений требует прист льного вним ния к д нной технической проблеме.

процессе бурения используемые буровые р створы должны обеспечить устойчивость несцементиров нных грунтов. сыщение обр зцов несцементиров нного грунт буровым р створом позволило выяснить, что н физическое состояние грунт зн чительное влияние ок зыв ют структурно-мех нические и реологические п р метры бурового р створ .

опост вление сост в и свойств буровых р створов, использующихся $\mathrm{p}$ зличными комп ниями в строительстве подводных переходов, т кже результ ты строительств подводных переходов пок зыв ют необходимость дифференциров нного подход к проектиров нию сост в и свойств бурового р створ в 3 висимости от горногеологических условий бурения, длины и ди метр проектируемого переход .

рот скив ние трубопровод . конч тельным результ том строительств переходов является прот скив ние трубопровод . сложнения в процессе прот скив ния трубопровод связ ны в основном с прохождением криволинейных уч стков скв жины в грунт х, склонных к обрушению, гл вным обр зом, гр вийно-г лечниковых (иногд с включениями в лунов) и крупнообломочных м тери лов. этих уч стк х отмеч ется зн чительное увеличение н грузок при одновременном снижении скорости прот скив ния. то обусловлено недост точным р спределением н грузки (положительной или отриц тельной пл вучести), необходимой для изгиб трубопровод . оэтому появляются р спорные усилия н криволинейных уч стк х тр ектории скв жины. н чительные усилия р спор способны вызв ть большие конт ктные н грузки, при н личии в скв жине и н ее стенк х обломков твердой породы - привести к повреждению изоляционного покрытия. ля предотвр щения возможности появления подобных явлений осуществляют 6 лл стировку трубопровод путем з ливки в него воды.

птимизиров ть процесс б лл стировки трубопроводов р зличных ди метров позволяет н литическое моделиров ние движения трубопровод . . . вчинниковым был произведен р счет усилий по прот скив нию трубопровод через пробуренную скв жину. роведенные р счеты пок зыв ют, что для трубопровод ди метром $D=530$ мм и толщиной стенки $\delta=12$ мм полное 3 полнение трубопровод водой не д ет положительного эффект , т к к к полый трубопровод и полностью з полненный трубопровод имеют близкие весовые х р ктеристики.

ри протягив нии трубопровод большего ди метр основные з кономерности изменения усилий меняются в 3 висимости от объем 6 лл стировки. т к ждого доб в- 
ленного объем воды достиг ется определенный эффект, уменьш ющийся по мере д льнейшего движения трубопровод . счеты пок зыв ют, что в этом случ е ч сть трубопровод (переходн я зон ) не конт ктирует со стенк ми скв жины, з счет этого усилие протягив ния должно сниж ться.

тилиз ция отходов бурения. дной из сложных проблем является проблем утилиз ции бурового р створ и шл м, нейтр лиз ция его вредного воздействия н объекты природной среды. ее решении в жн я роль отводится $\mathrm{p}$ зр ботке методов и технологии утилиз ции, и обезврежив ния ук з нных отходов бурения. чевидно, что созд ние систем з крытого цикл и рециркуляции, т кже уменьшение токсичности буровых р створов уменьш ет р сходы н утилиз цию. то снизит объем отходов бурения для утилиз ции. уществуют следующие методы утилиз ции отходов бурения.

- $\quad$ мый простой метод ликвид ции мб ров включ ет обезвожив ние отр бот нного бурового р створ ( ), з сыпку и з хоронение его твердых ост тков в специльных мб $\mathrm{p} \mathrm{х.}$

- спользов ние в сельском хозяйстве. то х р ктерно только для недиспергиров нных буровых р створов с низким содерж нием солей, т кже известковых и гум тных буровых р створов, применяемых для строительств нефтяных и г зовых скв жин.

- $\quad$ нефтяной и г зовой промышленности используется подвижн я систем обр ботки воды, полимерной флокуляции и отверждения ост тков в мб $\mathrm{p}$ х.

- $\quad$ зр бот ны методы уд ления отр бот нных буровых р створов, н пример, путем импульсной и ф кельной сушки и сжиг ния. дн ко при этом з грязняется воздух. тот метод связ н с высокими з тр т ми энергии.

- $\quad$ едл г ется к использов нию б ктери льн я дегр д ция. н стоящее время прод ют сухие $з$ мороженные б ктерии и пит тельные п кеты для ускорения р зложения ре гентов в мб р х. етод эффективен, но требует для своей ре лиз ции зн чительного времени.

се известные методы перер ботки буровых р створов включ ют в себя отделение твердой ф зы от воды путем ко гуляции. то можно осуществить к к в мб ре, т к и в специ льных блок х по перер ботке р створ .

нные мероприятия осуществляются посредством ввод в сост в отр бот нного бурового р створ соединений, $\mathrm{p}$ зруш ющих структуру бурового $\mathrm{p}$ створ ре гентов в их сост ве. кими соединениями являются гидроксихлорид люминия, сульф ты люминия и желез, гидролизов нный поли крил мид, водор створимый полимер к тионный ( -402), известь нег шен я и др. нные соединения вследствие своей очень высокой гидрофильности свор чив ют полимеры и приводят т кже к ко гуляции глины. $\quad$ результ те этих процессов имеет место р зделение р створ н твердую ф зу и осветленную воду. д льнейшем н блюд ется седимент ционное ос ждение твердой ф зы. осле прохождения опис нных процессов осуществляется уд ление жидкой ф зы.

сновным путем снижения экологической н грузки является, прежде всего, снижение объем потребляемого р створ . тр бот нный р створ, в свою очередь, должен быть р зделен н твердую и жидкую ф зу. то лежит в основе всех технологий по перер ботке буровых р створов.

росуммиров нный н ми опыт строительств методом н клоннон пр вленного бурения пок зыв ет, что существует ряд специфических требов ний к технологии их строительств . ч стности, это требов ния к буровому оборудов нию, ре лизуемой технологии р сширения, применяемым буровым р створ м, промывке скв жин в процессе р сширения. нные требов ния обусловлены геологическими условиями строительств и его конструктивными п р метр ми. облюдение д нных требов ний позволило р зр б тыв ть прогр ммы по строительству в сост ве проектной документ ции, обеспечить контроль процесс строительств и его успешное з вершение.

писок литер туры

1. ехнология бурения нефтяных и г зовых скв жин: учеб. для вузов / . . опов, . . пив к, . . кбул тов и др.; под общей ред кцией . . пив к . .. « едр - изнесцентр», 2003. - 509 с. 


\section{Сведения об втор $x$}

пектор рий осифович, д. директор "зиром промг з», г. оскв, тел. 8(495)5044270,e-mail: promgaz@promgaz.ru

р футдинов риф киевич, д. т. н., гл вный н учный сотрудник "зпром промг з», г. оскв, тел. 8(495)5044378, e-mail: z.sharafutdinov@promgaz. gazprom.ru

олоф ст ергей еонидович, д. $m$. н, профессор $\kappa$ федры "ибернетические системы», юменский госуд рственный нефтег зовый университет, г. юмень,тел.8(3452)488111,e-mail:trasser@inbox.ru
Information about the authors

Spektor Yu. I., Doctor of Engineering, General Director of OJSC «Gasprom promgas», phone: 8(495)5044270, e-mail:promgaz@promgaz.ru

Sharafutdiniov Z. Z., Doctor of Engineering, chief scientific worker of "Gasprom promgas», phone: 8(495)5044378, e-mail: z.sharafutdinov@promgaz. gazprom.ru

Golofast S. L., Doctor of Engineering, professor of the chair "Cybernetic systems», Tyumen State Oil and Gas University, phone: 8(3452)488111,e-mail: trasser@inbox.ru 